See Article page 1097.

\section{Commentary: Gold or silver? Value of cardiac magnetic resonance imaging over echocardiography in Ebstein's anomaly}

\author{
M. Yasir Qureshi, MBBS, ${ }^{a}$ and \\ Joseph A. Dearani, MD ${ }^{\mathrm{b}}$
}

Cone repair is currently the standard surgical operation to improve tricuspid valve (TV) function and restore the position of the TV functional orifice to the right atrioventricular groove, with excellent surgical outcomes. ${ }^{1}$ Imaging studies performed in the diagnosis and treatment of Ebstein's anomaly (EA) includes echocardiography routinely and cardiac magnetic resonance (CMR) imaging selectively. In general, echocardiography is superior for anatomic assessment of TV, and CMR imaging is considered the gold standard for evaluating the size and function of the right ventricle $(\mathrm{RV})$. Challenges with the routine use of CMR imaging include high cost and the potential need for general anesthesia in young children for image acquisition. In addition, the method of RV measurement by CMR imaging is quite variable among institutions in terms of what is actually measured, with specific reference to the inclusion/exclusion of the atrialized $\mathrm{RV}(\mathrm{aRV})$ relative to the functional RV (fRV). These inconsistencies in the literature have resulted in confusion about long-term RV remodeling in EA.

In this issue of the Journal, Neijenhuis and colleagues ${ }^{2}$ provide a single-institution retrospective review of patients with EA who underwent cone repair. Their primary objectives were to assess the long-term competence of TV and biventricular function by CMR imaging. The secondary objective was to assess the biventricular reverse remodeling

\footnotetext{
From the ${ }^{\mathrm{a}}$ Division of Pediatric Cardiology, and ${ }^{\mathrm{b}}$ Department of Cardiovascular Surgery, Mayo Clinic, Rochester, Minn.

Disclosures: The authors reported no conflicts of interest.

The Journal policy requires editors and reviewers to disclose conflicts of interest and to decline handling or reviewing manuscripts for which they may have a conflict of interest. The editors and reviewers of this article have no conflicts of interest.

Received for publication Nov 4, 2020; revisions received Nov 4, 2020; accepted for publication Nov 5, 2020; available ahead of print Nov 19, 2020.

Address for reprints: Joseph A. Dearani, MD, Department of Cardiovascular Surgery, Mayo Clinic, 200 First St, SW, Rochester, MN, 55905 (E-mail: jdearani@mayo. edu).

J Thorac Cardiovasc Surg 2021;161:1109-10

$0022-5223 / \$ 36.00$

Copyright (c) 2020 by The American Association for Thoracic Surgery

https://doi.org/10.1016/j.jtcvs.2020.11.016
}

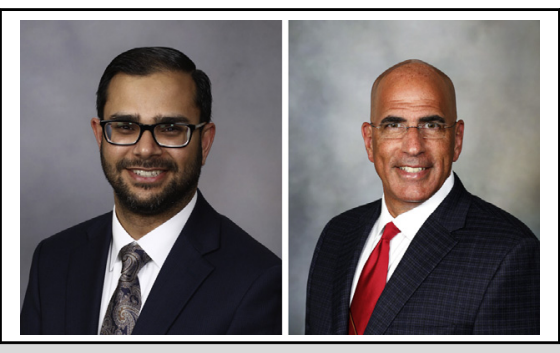

M. Yasir Qureshi, MBBS, and Joseph A. Dearani, MD

\section{CENTRAL MESSAGE}

Cardiac magnetic resonance imaging and echocardiography provide complementary information about Ebstein's anomaly

in the preoperative evaluation and postoperative follow-up.

after cone repair. CMR imaging was performed before cone repair and postoperatively at a median follow-up of 5.1 years. Although the authors provided extensive details of 50 patients, only 12 actually met the selection criteria for the primary and secondary objectives of this study.

Key findings included the following:

1. TV function remained good through the follow-up period (3.1-6.1 years). Average TV regurgitant fraction was only $10 \%$ postoperatively, compared with $69 \%$ preoperatively. This closely correlated with qualitative assessment by echocardiography; however, the authors do not state whether or not this comparison was blinded.

2. RV and left ventricular (LV) ejection fractions remained unchanged between the 2 CMR scans, despite a decrease in preload due to decreased tricuspid regurgitation and altered septal configuration after repair.

3. RV stroke volume decreased and LV stroke volume increased during follow-up; however, the cardiac index remained unchanged.

4. RV indexed end-diastolic and end-systolic volumes did not show statistically significant decreases after surgery. This is counterintuitive and likely related to how RV volumes were measured. Preoperatively, only the fRV volume was included, ignoring the aRV and thereby significantly decreasing the measured RV volumes. Had the authors measured the "anatomic RV" $(\mathrm{aRV}+\mathrm{fRV})$ both preoperatively and postoperatively, we suspect that there would have been a significant decrease in these volumes after repair. For this reason, we recommend that CMR RV volumes include the 
complete anatomic RV that consists of both aRV and fRV preoperatively. ${ }^{3}$

5. The LV end-diastolic volume increased postoperatively owing to the ventricular septal shift back toward the RV after surgery and better forward flow from the RV, resulting in improved LV preload. The LV end-systolic volume did not show a significant change.

The major limitation of this study is the small number of patients that had follow-up CMR imaging. Although it is well recognized that $\mathrm{CMR}$ imaging can provide valuable data and is superior in quantifying ventricular volumes to echocardiography, the routine use of CMR scans in patients who are doing clinically well might not be justifiable given the cost, the potential need for general anesthesia in small children, and the fact that most surgeons rely on echocardiography to guide feasibility and strategies for tricuspid repair. This highlights the need for a prospective CMR imaging study for patients with EA undergoing cone repair, preferably as a multicenter study to provide a definitive assessment of late outcome regarding RV remodeling. Assessment of RV deformation by feature tracking on CMR imaging also may provide insight into the RV myopathy of EA. Such natural history data are imperative for assessing adjunctive therapeutic options for RV myopathy, for example, cell-based therapy. ${ }^{4}$

\section{References}

1. Holst KA, Dearani JA, Said S, Pike RB, Connolly HM, Cannon BC, et al. Improving results of surgery for Ebstein anomaly: where are we after 235 cone repairs? Ann Thorac Surg. 2018;105:160-8.

2. Neijenhuis RML, Tsang VT, Marek J, Issitt R, Bonello B, Von Klemperer K, et al. Cone reconstruction for Ebstein anomaly: late biventricular function and possible remodeling. J Thorac Cardiovasc Surg. 2021;161:1097-108.

3. Qureshi MY, O'Leary PW, Connolly HM. Cardiac imaging in Ebstein anomaly Trends Cardiovasc Med. 2018;28:403-9.

4. Holst KA, Dearani JA, Qureshi MY, Wackel P, Cannon BC, O'Leary PW, et al. From safety to benefit in cell delivery during surgical repair of Ebstein anomaly: initial results. Ann Thorac Surg. 2020 [In press].
See Article page 1097.

\section{Commentary: Cone reconstruction for Ebstein's anomaly is here}

\section{to stay}

\author{
Pedro J. del Nido, MD
}

Cone reconstruction of the tricuspid valve to treat valvular regurgitation in Ebstein's anomaly has now become the accepted method for reproducibly improving tricuspid valve function. Since the early description of the cone technique and initial results reported by DaSilva and colleagues, ${ }^{1}$ several centers have adopted the technique and

\footnotetext{
From the Department of Cardiac Surgery, Boston Children's Hospital, and Harvard Medical School, Boston, Mass.

Disclosures: The author reported no conflicts of interest.

The Journal policy requires editors and reviewers to disclose conflicts of interest and to decline handling or reviewing manuscripts for which they may have a conflict of interest. The editors and reviewers of this article have no conflicts of interest.

Received for publication Nov 30, 2020; revisions received Nov 30, 2020; accepted for publication Dec 1, 2020; available ahead of print Dec 5, 2020.

Address for reprints: Pedro J. del Nido, MD, Department of Cardiac Surgery, Boston Children's Hospital, Bader 273, 300 Longwood Ave, Boston, MA 02115 (E-mail: Pedro.delnido@childrens.harvard.edu).

J Thorac Cardiovasc Surg 2021;161:1110-1

$0022-5223 / \$ 36.00$

Copyright (c) 2020 by The American Association for Thoracic Surgery

https://doi.org/10.1016/j.jtcvs.2020.12.004
}

Check for updates

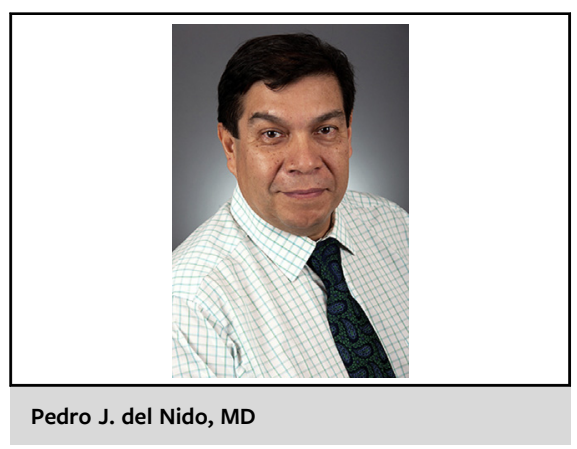

CENTRAL MESSAGE

Cone reconstruction of a regur-

gitant Ebstein's tricuspid valve is

associated with improved valve

function and global biventricular

function and filling late after

surgery.

reported their early and mid-term results..$^{2-4}$ The basic concept of the cone procedure relies on mobilization and clockwise rotation of valve tissue to create a cone-like valve morphology with valve tissue attachment at the anatomic atrioventricular junction and support cords originating from the right ventricular apex. Reduction or plication of 